\title{
Exploring Students' Experiences Toward Online and Offline Assessment
}

\author{
Fitriah \\ English Language Education Department, \\ UIN Sunan Ampel Surabaya \\ Mutmainah \\ English Language Education Department, \\ UIN Sunan Ampel Surabaya
}

\begin{abstract}
Assessment is a series of information about learning outcomes and achievement of competencies from students. There are two modes that are generally used by teachers to conduct assessments, namely online and offline assessment. The purpose of this study is to explore experiences in using online and offline assessment. this study applied qualitative research.The participant of this study are students English Education in UINSA especially at six semester. Consist 15 participants from each class namely A class four students, B class four students, C class four students, and D class three students. To collect the data researcher conducted by interview. The result is most students like online assessment because they are easy to access and the value they get can only be seen by themselves.Some of the students also liked the two ways the teacher gave values between online assessment and offline assessment. The researcher hope this research can beas a reference for other researcher who wants to conduct a study similar topic.
\end{abstract}

Keywords: assessment, online assessment, offline assessment

\section{INTRODUCTION}

Assessment is a way and tool to get a series of information about learning outcomes and the achievement of competencies from students.According to Gronlun (2012), states that assessment as a systematic process of gathering, analyzing, and interpreting information to determine the extent to which students reach the goal. Similarly, Brown (2011:4) argue that assessment is an ongoing process that encompasses a much wider domain. To do an assessment, a teacher should consider many aspects in determining the final scores of the students. In addition to the mid-semester and final semester scores, the teacher should also pay attention to the students` participation, motivation, presentation, performance, paper, presence, homework, etc.all of those are required by students' to get pass in next

\author{
Hoiriyanto \\ English Language Education Department, \\ UIN Sunan Ampel Surabaya \\ Lilik Faridatul K. \\ English Language Education Department, \\ UIN Sunan Ampel Surabaya
}

level. Assessment has two functions, namely formative and summative. Brown (2011) points out that formative assessment focuses on the process of "forming" students' competencies and skills and aims at leading them to continued growth. He also reiterates the importance of feedback in formative assessment. Conversely, summative assessment measures, or summarizes, what has been learned at the end of a course or unit of instruction. It is about looking back and taking stock of what has been accomplished. The aims of teachers' conducting assessment is used to provide feedback or feedback to the teachers to be used as a basis when correcting and justifying the learning process and also conducting remedial for students. While summative is a function as a determinant of student learning value in one particular subject, so that it can then be used as material to provide reports, determine the increase in class and determinant of student's failure success in the class.

There are two modes that are generally used by teachers to conduct assessments, namely online and offline assessment. Worthen and Sanders(2010) statesthat online assessment is a way for teachers to assess students by using technology. Kind of tools that are usually used by teachers to conduct online assessments such as Schoology, Edmodo, Google Classroom, Courser, etc. Hornby (2009) argue that the use of online assessment give students instant feedback, unlike paper examinations in a traditional classroom learning session. Online assessments give you the option of taking practice tests whenever you want. Students do not always must be in classroom setting to take assessments. Some assessments are Internet-based, which allows students to do assessment at home or anywhere else he or she likes. Otherwise the beneficial for the teacher is the teacher can be reduce level cheating of students, allow teachers to quick give feedback or scoresto students even group or individual. Online assessment not only have many advantages to students, but also online assessment have disadvantages such as needed internet connection, needed money to buy quota internet, etc. 
Whereas offline assessment is the way the teacher takes students' grades directly in the classroom. Examples of offline reviewers are usually in the form of paper, orally test as directly, project make something, and etc. generally the teacher will conduct an offline assessment when the technology in a school is not available. We can usually find this in rural areas where there is still a lack of technology equipment that not supports learning process in the class. Offline assessment also has advantages and disadvantages. The advantages of offline assessment is students can get feedback from teacher directly. It's mean that teacher can help students more understand about feedback that will convey by teacher. Simple and easy to do it because the students just need paper, then they can do it directly. Even offline assessment simple to conduct but there are disadvantages of offline assessment such as spend more time than online assessment, for students have to come to the class while for teacher have to give scores as manually. The participant of this study are students in sixth semester because they have already learned about kinds of tools that use in online assessment in CALL (Computer Assisted Language Learning) and IBLT (Internet Based Learning Teaching). Its mean that they are have a lot experiences using technology to integrate in learning process. Another participant is we go to school then conduct interview students and teachers perspective about online and offline assessment based on their opinion.

Based on previous study of Claire Hewson and John Charlton from University of Baht, The issues regards the use of online and offline assessment is not yet finished since the previous study only discussed one sides use the type of assessment in a particular skill. Seen that assessment can be conduct throw online and offline assessment. That's why we conduct it because we want to know

1. What are students have experiences in using online and offline?

2. Which assessment do students prefer to do it in EFL classroom?

3. What are the challenges in using online and offline assessment?

\section{METHOD}

\section{Research Designed}

To answer those three research questions, this study applied qualitative research. According to Hancock and Wandridge (2007) stated that qualitative research is concerned with developing explanation of social phenomena. Cressweel based on his book also stated that qualitative research is descriptive studies are design for finding fact about actual phenomena through the process of collecting data, analyzing and interpreting based on the analyze result

\section{Participants}

The participant of this study are students English Education in UINSA especially at six semester. Consist 15 participants from each class namely A class four students, B class four students, $\mathrm{C}$ class four students, and D class three students. The reason why we choose them because those all students already got many experiences in CALL and IBLT classroom in previous semester in using online and offline assessment with who got the best score in each class and also recommendation by teacher.

\section{Data Collection}

Data collection it's the most important thing that we have to do to answer this research. To collect the data we conducted by interview in faculty of Tarbiyah.

\section{Data Analysis}

After we conducted the interview. We have to analyze the data that we already got from the participants. There are four steps that we do to analyze the data such as transcript, highlight, coding, and grouping or category.

\section{Transcript}

After I finished conduct the interview, I will transcript the data from interviewers.

\section{Highlight}

Then, after transcript, I will read and highlight the answer that we need.

\section{Coding}

We do the coding when the data too long. So, we just take the the important point that we need.

\section{Category/Grouping}

The last step, I will categories the answers based on the theme that related with students experiences, students preferences and students challenges in using online and offline assessment. 
III. FINDINGS AND DISCUSSION

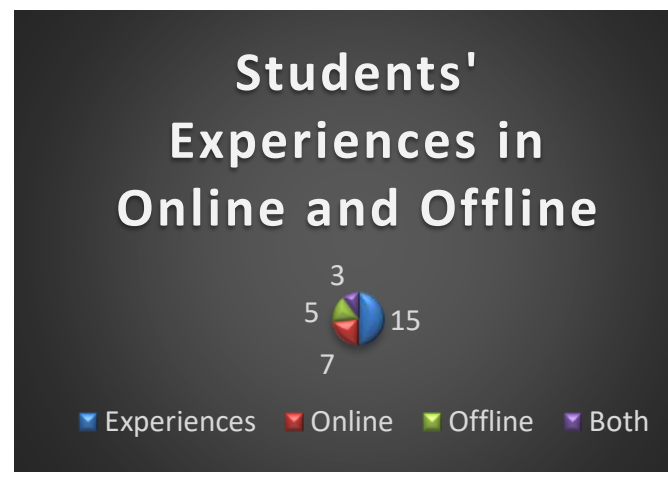

II. FIGURE 1.1

Based on figure 1.1 we show that all participants had ever experienced in using online and offline assessment. We got the data that 7 participants prefer to online assessment because they stated that online assessment flexible to do it. It's mean that students can do wherever and anytime that they want. Another thing that they more prefer to do online assessment because by using online assessment they can keep their score without anyone know about the score that they got. While 5 participants said that they more prefer to do offline assessment because they thing that offline assessment more effective when they got feedback from the teacher. They also said that important thing when they used offline assessment they not worried about signal or connection, they can asking directly to the teacher without wait long time. Others 3 participants argue that they prefer to both of them (online and offline). They said that online and offline assessment it's the same interest to do it.

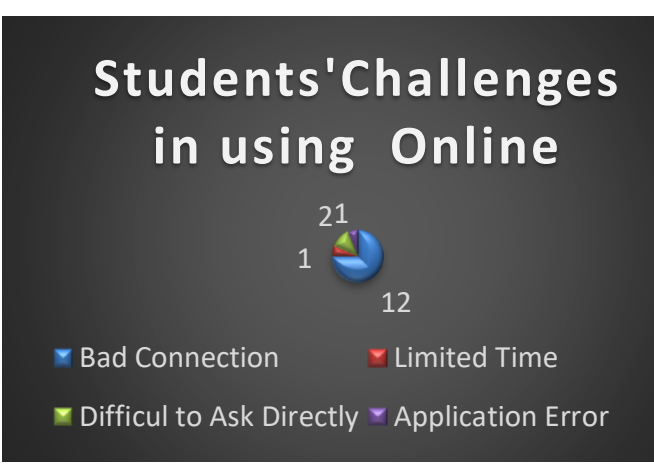

Figure. 1.2

Based on the data that the researchers took, the challenges faced by participants when getting online assessments are that most of them say bad internet connection is the most common thing when they get an online assessment, when their value has appeared but they cannot access it because the signal is bad, this is a common thing that often happens when using things that smell online. some of the participants also said that limited time was also their challenge because sometimes the online scoring system could only be seen briefly like a quiz value. Difficult ask directly also becomes a challenge when they get grades online or get feedback from their lecturers, it is difficult to ask questions directly because they do not meet directly with the lecturer and the last problem is the application error so they cannot access their grades online.

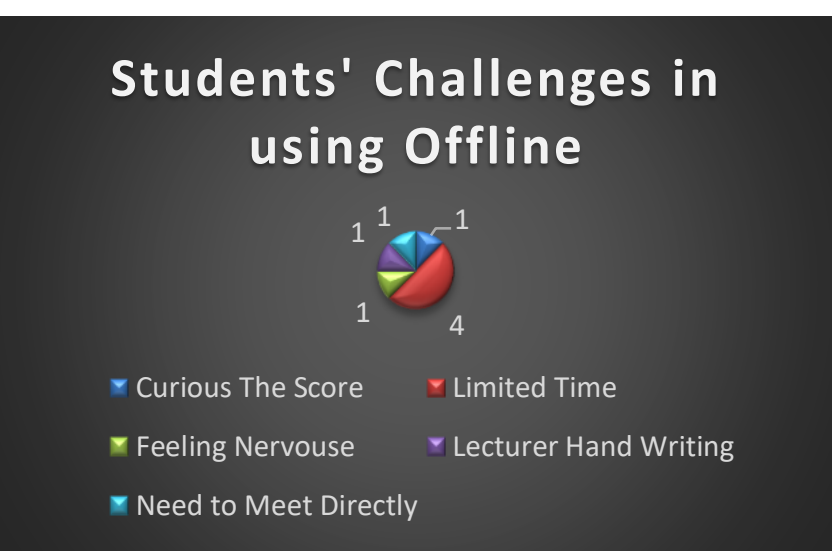

Figure. 1.3

Students challenges when getting offline assessment are that the most common thing is limited time because the lecturer should directly give score or feedback for the students in the class when the students have any questions related to their score or their assessment they can not directly ask to the lecturer because the other students also want their score. The next challenges is need to face to face because students should come to the class and the lecturer directly give the score or feedback directly when they meet face to face in the classroom. The next is feeling nervouse because some of the students not confidence when they come in front of class and not confidence when they face to face with lecturers. And the next is lectures handwriting, that is also common thing because some of lecturers has good handwriting and some of them does'nt has good hand writing this problem make some students confuse to read the feedback when the lecturer give them hand writing. And the last challenges of offline assessment is curious the score that it happen when other students want to know the score the other students and it distrubs their prifacy.

\section{CONCLUSION}

In the conclusion of exploring students experiences toward online and offline assessment is according the reseacher found that almost of student prefer to online assessment because flexible to 
access anytime and anywhere that they want and score prifacy so their score does'nt know the other students. And then some of the students prefer to offline assessment because they can getting feedback directly from the lecturers, more effective because they can remember and understand their error, and mot worried about signal because offline assessment not use technology or internet. And some of the students prefer to both online and offline assessment because online and offline have weaknesses amd strenght for each and that is very interesting to each other.

The limitations of the study is the participant is students who had sixth semester of English Teacher Education Department at State Islamic University of Sunan Ampel Surabaya. In this study the reseacher chooses the participant by interview. And the next limitation is the reseacher just choose students to become a participant not lecturer as a participant.

The reseacher hope to future reseach also ask for the opinions of the lecturers because the assessment is very closely related to the assessment process given by the teacher and expanding participants to become interviewers such as adding several classes so the data obtained is more valid.

\section{REFERENCES}

[1] Banta, T.W., \& Palomba, C.A. (2015). Assessmnet essentials : Planning, implementing, and impoving assessment in higher education. San Fransisco, CA : John Wiley \& Sons, Inc.

[2] Brown, H. Douglas. (2011). Language Assessment: Principles and Classroom Practices. Fourth Edition. White Plains, NY: Pesrson Education.

[3] Buchanan, T. (2000). The efficacy of WWW- mediated formative assessment. Journal of Computer Asisted Learning, 16,193-200.

[4] Cooper, J., (2003). Gender and computers : Understanding the digital divide. Hwah, NJ : Lawrence Erlbaum.

[5] Franklin, M.P. (2003). Has student learning been improved by the use of online and offline formative assessment opportunities? Australian Journal of Educational Technology, 87-89.

[6] Henley, D. C. (2003). Use of Web-based formative assessment to support student learning in a metabolism/ nutrition unit. European Journal of Dental Education, 7, 116-122.

[7] Marius PETRISOR, M.M.(2011). Online Assessment System. Applied Medical Information, 28,1-6.

[8] Norman, E. Gronlund. (2012). Measurement and Assessment in Teaching. $10^{\text {th }}$ Edition. White Plains, NY: Pearson Education.

[9] Ricketts, C.,\&Wilks, S.J. (2002). Improving student performance trough computer based assessment : Insight from recent research. Assessment and Evaluation in Higher Education, 27(5), 475-479.

[10] Suskie, L. (2009). Assessing student learning : A practical guide. San Fransisco, CA: Jossey- Bass.

[11] https://journals.sagepub.com/doi/abs/10.2304/plat.2007.6.1 .37

[12] https://www.sciencedirect.com/science/article/pii/S104160 $\underline{8016300188}$ 